УДК 904.4 (477.73) «18/19» (091)

DOI: https://doi.org/10.33782/eminak2019.1(25).209

\title{
О РАСКОПКАХ ОЛЬВИИ В АRСНӒОLOGISCHER ANZEIGER (1891-1914 ГГ.)
}

\author{
Александр Кузьмищев \\ Институт археологии НАН Украины (Киев, Украина) \\ e-mail: a.kuzm@ukr.net \\ ORCID: https://orcid.org/0000-0003-2718-7111
}

У статті розглядаються замітки на сторінках німецького журналу Archäologischer Anzeiger, присвячені розкопкам Ольвії, з 1891 по 1913 рр. Описується їх зміст, вказується, що частина опублікованої там інформації не має аналогів у вітчизняних виданнях. У 1891 р. була надрукована стаття про придбання знахідок з Ольвії Боннським університетом (Г. Лешке). У 1897 р. вийшла замітка, присвячена археологічним колекціям Північного Причорномор'я (Г. Драгендорфа). У 1899, 1901-1903 рр. інформацію про археологічні знахідки публікує Г.Є. Кізеріцький. Але найбільш докладні відомості про розкопки Ольвії були опубліковані Б.В. Фармаковським, який надав інформацію про археологічні дослідження за 1903-1913 рр.

Ключові слова: історія археологї̈, Ольвія, Archäologischer Anzeiger, Б.В. Фармаковський

Представители научного археологического сообщества конца XIX - начала XX века тесно сотрудничали друг с другом, обмениваясь информацией об опубликованных работах и проведенных исследованиях на страницах не только отечественных, но и зарубежных изданий. Не были исключением и ученые-антиковеды специализирующиеся на изучении древностей Северного Причерноморья. Например, с 1887 по 1891 гг. тогда еще начинающий историк античности, Э.Р. фон Штерн публикует в журнале «Revue de philologie, de litterature et d'histoire anciennes» (пер. с фр. «Журнал филологии, литературы и древней истории») на французском языке литературные обзоры выходящих в Российской империи исследований по античности. Таким образом, он знакомил зарубежных филологов и историков, специализирующихся на античности, с новинками соответствующей научной литературы Российской империи, охватив период с 1884 по 1890 год.

К сожалению, историография публикаций, посвященных археологическим исследованиям Северного Причерноморья в европейских изданиях рубежа XIX-XX вB., насколько известно автору, практически отсутствует. По рассматриваемой теме существует лишь подстрочное примечание в учебнике Сергея Александровича Жебелева, где он, сетуя на то, что многое из результатов раскопок до Первой мировой войны до сих пор не опубликовано в должной мере, отмечает, что «Очень полезны были издававшиеся до войны ежегодные краткие отчеты Б.В. Фармаковского в берлинском Archäologischer Anzeiger, но они, конечно, не могут заменить больших публикаций»1.

Отсутствие статей, посвященных анализу заметок в зарубежных изданиях о ходе раскопок в Северном Причерноморье, обусловлено тем, что в период создания таких

\footnotetext{
1 Жебелев С.А. Введение в археологию. Ч. 1: История археологического знания. Петроград: Наука и школа, 1923. С. 142.
} 
заметок в этом не было необходимости, а позже, вплоть до конца XX в., доступ к зарубежной литературе, тем более узкоспециализированной, был затруднен. В то же время, учитывая возросший интерес к истории становления археологической науки, а также изучение на новом научно-методическом уровне результатов раскопок прошедших времен, такое исследование представляется актуальным. Дело в том, что иногда информация, которая там печаталась, не дублировалась в отечественных изданиях и является единственным источником, расширяющим наши познания как о проведенных раскопках, так и найденных памятниках материальной культуры.

Одним из наиболее важных немецкоязычных журналов в области археологии со второй половины XIX в. является «Archäologischer Anzeiger» (пер. с нем. «Археологический вестник»), на страницах которого публиковались, в числе прочего, и короткие результаты проведенных археологических работ в различных регионах мира. Также, в качестве приложения, все четыре номера журнала за год входили в многотомное издание «Jahrbuch des Deutschen Archäologischen Instituts» (пер. с нем. «Ежегодник Немецкого археологического института»).

Впервые внимание Ольвии было уделено на

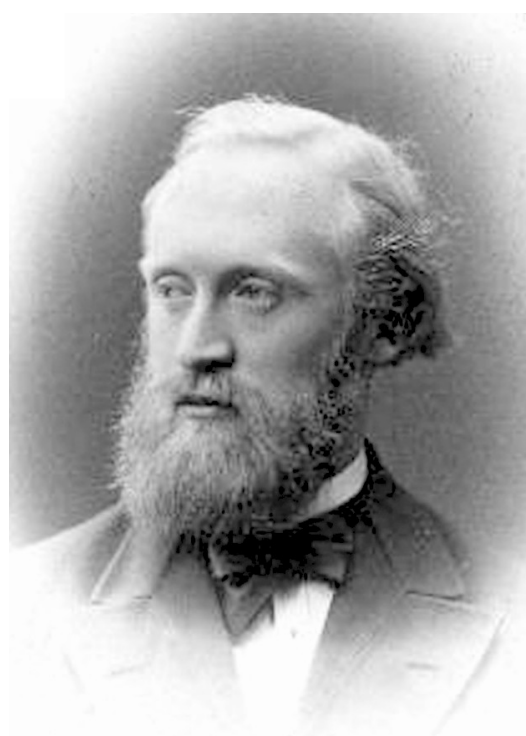
страницах «Археологического вестника» в 1891 г., когда была напечатана статья о приобретении археологических находок Боннским университетом, в том числе и тех, которые происходили из грабительских раскопок Ольвийского некрополя. Автором статьи был профессор классической археологии Георг Лёшке (1852-1915) (рис. 1) - сторонник сближения истории и археологии, учитель и научный руководитель упоминаемого выше Э.Р. фон Штерна. Будучи на момент написания статьи главой художественного музея при Боннском университете, Г. Лешке опубликовал новоприобретенные вещи на достаточно высоком для своего времени научном уровне. В начале статьи автор отметил, что приобретение 50 глиняных горшков, обнаруженных на ольвийском некрополе, является очень важным приобретением для музея, позже добавив, что хотя среди них нет предметов «уникальной художественной

Рис. 1. Георг Лёшке (1852-1915) ценности», но вместе они дают широкую ретроспективу античной жизни с VI в. до н.э. по римскую эпоху включительно.

В 1897 г. была напечатана заметка², посвященная археологическим коллекциям в северопричерноморском регионе, происходящими, в том числе, из грабительских раскопок Ольвии. Она была написана немецким археологом Гансом Драгендорфом (1870-1941) (рис. 2) - исследователем классической и провинциально-римской археологии, впервые создавшем классификацию terra sigilata. Позже он будет профессором Базельского университета (1898-1902), первым директором Римско-

\footnotetext{
2 Dragendorff H. Archäologische Mitteilungen aus Süd-Russland // Archäologischer Anzeiger. 1897. № 1. S. 1-8.
} 
германской комиссии - Römisch-Germanische Kommission (RGK) (1911-1922), генеральным секретарем Немецкого археологического института (1922-1932), профессором Фрайбургского университета (1922-1938).

Собирая материал для диссертационного ис-

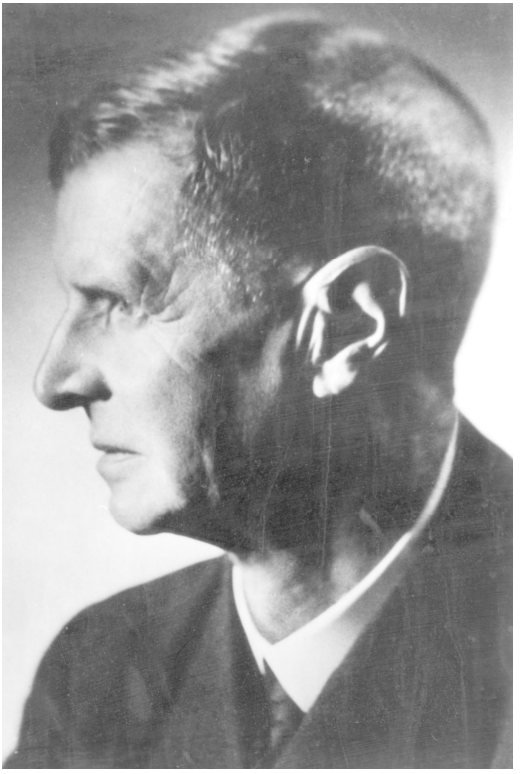

Рис. 2. Ганс Драгендорф (1870-1941) следования посвященного классификации римской terra sigilata, исследователь ознакомился, в числе прочих, с музейными и частными коллекциями Кишинева, Одессы, Херсона. В частности, автор описал свое знакомство с коллекцией Ивана Кассиановича Суручана - «Музеем древностей Понта Скифского», многие из находок которой происходили из Ольвии, особенно выделив многочисленные изделия из стекла и «богатые находки из металла, особенно золото, в которых Южная Россия не имеет себе равных». При этом автор заметки отметил, что, к сожалению, фальсификаторы недавно начали подделывать такие находки, поэтому при их анализе необходима максимальная осторожность.

Описывая свое пребывание в Херсоне, Г. Драгендорф отмечает, что этот город является местом для наблюдений и собирательства находок из Ольвии, которые в большинстве, к сожалению, добываются незаконными методами, но ситуация меняется к лучшему благодаря энергичной деятельности местного правительства против охотников за сокровищами и скупщиков краденого, что является заслугой Виктора Ивановича Гошкевича. Автор отмечает, что В.И. Гошкевич уже собрал коллекцию античных находок из Ольвии и других мест, которые пока размещаются в его квартире, но в будущем создание музея неизбежно.

В 1899 и 1901-1903 гг. на страницах Археологического вестника информацию об археологических находках и раскопках Юга России публикует Гангольф Егорович Кизерицкий (1847-1904) - археолог, главный хранитель отделения древностей Императорского Эрмитажа (так его звали на русский манер, а настоящее имя было Рейнгольд Густав Гангольф фон Кизерицкий).

В первой заметке ${ }^{3}$ Г.Е. Кизерицкого от 21 мая 1899 г. о раскопках Ольвии не упоминается. Там подана информация об исследованиях предшествующего года в Пантикапее, Херсонесе, Тавриде в целом, а также на Северном Кавказе. Но уже в публикации за 1901 г. $^{4}$, где Г.Е. Кизерицкий описывал раскопки за 1899-1900 гг, он обращает внимание и на Ольвию Понтийскую, отметив, что она продолжает давать множество интересных находок, но при этом, предположительно оттуда же поставляются апулийские вазы невысокого художественного уровня, которые до этого были неизвестны в данном регионе. Г.Е. Кизерицкий предположил, что это может быть связано с тем, что раньше в Ольвии не производилось столько нелегальных

\footnotetext{
${ }^{3}$ Kieseritzky G. Funde in Südrussland // Archäologischer Anzeiger. 1899. № 2. S. 56-57.

${ }^{4}$ Kieseritzky G. Funde in Südrussland // Archäologischer Anzeiger. 1901. № 2. S. 55-57.
} 
раскопок как в описываемое время (Ольвию начали массово грабить крестьяне изза голода 1900 года), но это мог быть и современный экспорт таких ваз из Италии в Одессу, поскольку «даже небольшие вазы оплачиваются коллекционерами в Одессе в десять раз выше, чем в Неаполе». Позже выяснилось, что второе предположение, о том, что вазы являются привезенными из Италии, оказалось верным.

В сообщении за 1902 г. Г.Е. Кизерицкий пишет, что в предшествующем 1901 г. в Ольвии и на о.Березань было найдено много керамики архаического периода, а также большая орнаментированная амфора более позднего времени и бронзовая статуэтка молодого человека, вероятно местного производства5.

В заметке за 1903 г.6 (где, соответственно, описывались археологические изыскания 1902 г.) были указано, что раскопки Ольвии проводил Б.В. Фармаковский, и далее шло перечисление самых интересных, с точных зрения автора, находок, как полученных в ходе раскопок, так и купленных у жителей села Парутино. В числе прочих артефактов были перечислены: три маленькие мраморные головы (мальчика, Аида и девушки, возможно Деметры или музы), бронзовые фибулы римского времени, фигурные сосуды в виде головы свиньи и барана, золотые ожерелье и две пары сережек ионийской работы.

К сожалению, в заметке не было сказано ни про сам ход раскопок, ни про раскрытые строительные остатки. При этом, как раз с 1902 г. Б.В. Фармаковский, благодаря договоренности Археологической комиссии с владельцем земель, где располагалось ольвийское городище, А.А. Мусиным-Пушкиным, впервые провел раскопки в городской черте Ольвии.

10 января 1904 г. Гангольф Егорович Кизерицкий скончался в Санкт-Петербурге. Его роль в деле публикации результатов раскопок на страницах Archäologischer Anzeiger взял на себя исследователь Ольвии Борис Владимирович Фармаковский (18701828) (рис. 3). Он с 1903 по 1914 гг., вплоть до Первой мировой войны, ежегодно писал подробные заметки посвященные археологическим исследованиям югозапада Российской империи. Эти публикации состоят из текстового описания того, что изучалось в прошедшем году и фотографий, не все из которых вошли в русскоязычные издания, например, в Отчеты археологической комиссии (ОАК) и Известия ар-

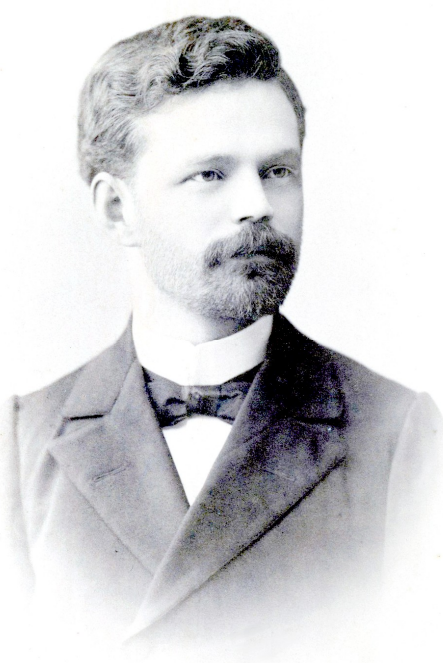

Рис. 3. Борис Фармаковский (1870-1928) хеологической комиссии (ИАК).

В описании археологических исследований 1903 г. ${ }^{7}$ Б.В. Фармаковский сначала останавливается на раскопках своих коллег (изучение Н.И. Веселовским Келермесских курганов, скифские курганы возле с.Журавка, раскрытые А.А.Бобринским и др.), после чего переходит к подробному изложению раскопок Ольвии. Б.В. Фармаковский описывает раскрытый им в 1902-1903 гг. «Зевсов курган» (склеп

\footnotetext{
${ }^{5}$ Kieseritzky G. Funde in Südrussland // Archäologischer Anzeiger. 1902. № 2. S. 44-46.

${ }^{6}$ Kieseritzky G. Funde in Südrussland // Archäologischer Anzeiger. 1903. № 1. S. 84-85.

7 Pharmakowsky von B. Funde in Südrussland im Jahre 1903 // Archäologischer Anzeiger. 1904. № 2. S. 100-107.
} 
II в. н.э.), обнаружение возле него фрагментов крепиды, отметив, сославшись на И.П. Бларамберга, что еще в 1820 годы большую ее часть разобрали для строительных нужд местные крестьяне.

Далее Б.В.Фармаковский отмечает, что курган был воздвигнут на месте жилой застройки Ольвии догетского времени, выделив, в ходе раскопок, семь различных культурных напластований, три из которых относились ко времени создания кургана, а в 4-м (датирующимся I в. до н.э.) был зафиксирован слой пожара и разрушений. Таким образом, разрушение Ольвии гетами в середине I в. до н.э. было впервые подтверждено на археологическом материале. Ниже шла застройка эллинистического времени, при раскопках которой была обнаружена мозаика, созданная из разноцветной гальки. К описанию раскопок Ольвии прилагались три фотографии, на первой был изображен склеп под «Зевсовым курганом», на второй запечатлен внешний вид «Зевсова кургана», третья отображала мозаику на полу здания эллинистического времени.

В последующие годы описание раскопок Ольвии и ее некрополя Б.В. Фармаковским в Archäologischer Anzeiger также, несмотря на сжатый объем, было информативным и сопровождалось фотографиями.

В заметке посвященной раскопкам 1904 г. Б.В. Фармаковский описывает обнаруженную им городскую оборонительную стену на склоне Заячьей балки (в римское время она станет западной частью цитадели, созданной в южной оконечности Ольвии), отметив, что стена была возведена не на античной полевке, но на субструкциях - искусственно построенных фундаментах, которые состояли из регулярно чередующихся очень узких (около 0,20-0,30 м) слоев почвы и пепла. Эта система придавала стене большую прочность, защищала от проседания и землетрясений, как сообщил автору раскопок профессор Николай Владимирович Султанов (1850-1908) - архитектор, искусствовед и историк архитектуры, директор Института гражданских инженеров, создатель собора Петра и Павла в Петергофе.

Из находок, обнаруженных в городской черте Ольвии в 1904 г., Б.В. Фармаковский особо отметил фрагменты двух эллинистических мраморных скульптур (их головы и ноги не сохранились) - фигуры стоящих женщин в хитоне и гиматии, возле одной из которых был ребенок в гиматии с птицей в левой руке.

Во время раскопок ольвийского некрополя Б.В. Фармаковский исследовал курган (4 м в высоту, 40 м диаметром) к западу от оборонительной стены возле Заячьей балки. В засыпи кургана было обнаружено два каменных склепа с двускатной крышей и более ранние грунтовые захоронения. Всего было найдено 37 погребений. Часть из них, в том числе каменный склеп, который был по центру кургана (№ 5), оказались ограбленными. Тем не менее, в другом каменном склепе, к северу от предыдущего (№ 28), несмотря на ограбление, был найден чернолаковый канфар конца IV в. до н.э. Часть текстовой информации по раскопкам и фотографий каменных склепов содержится только в Археологическом вестнике, не имея идентичных данных в Отчетах археологической комиссии.

В 1905 г. Борис Владимирович Фармаковский начал раскопки в северной части крепостной стены, расположенной в южной оконечности Ольвии. В ходе раскопок он пришел к выводу о том, что раскопанная им в прошлом году западная часть сте-

8 Pharmakowsky, von B.W. Die Funde in Südrussland im Jahre 1904 // Archäologischer Anzeiger. 1905. № 2. S. 57-65. 
ны и сейчас северная, составляли единую фортификацию, окаймлявшую террасу треугольной формы, обнесенную очень толстыми (до 4,70 м) сплошными стенами. Как писал исследователь, «окруженная такими стенами, Ольвия безусловно имела очень сильную твердыню, которая была необходима городу»9.

Худшая сохранность северной стены относительно западной объяснялась тем, что в начале XIX в. близлежащие крестьяне очень охотно разрушали древние кладки для своих нужд. Тем не менее, общее направление стен определялось еще довольно хорошо. Северная стена цитадели была расположена под прямым углом с востока на запад, лишь немного поворачивая на юг в своей восточной части. Ниже стены находились ямы более раннего времени, затрамбованные известняковым бутом, а также слоями глины и пепла (субструкциями). Также Б.Ф.Фармаковский предположил, что именно в северной стене располагались ворота в цитадель: «согласно топографическим условиям местности, северная сторона террасы является единственной, где может быть главный вход в замок». Ныне это предположение полностью подтвердилось. Б.Ф. Фармаковский продатировал первоначальное возведение стены не позднее IV до н.э., отметив, что она: «восходит к греческим временам, но была восстановлена в римские и снова служила уже римской Ольвии»10.

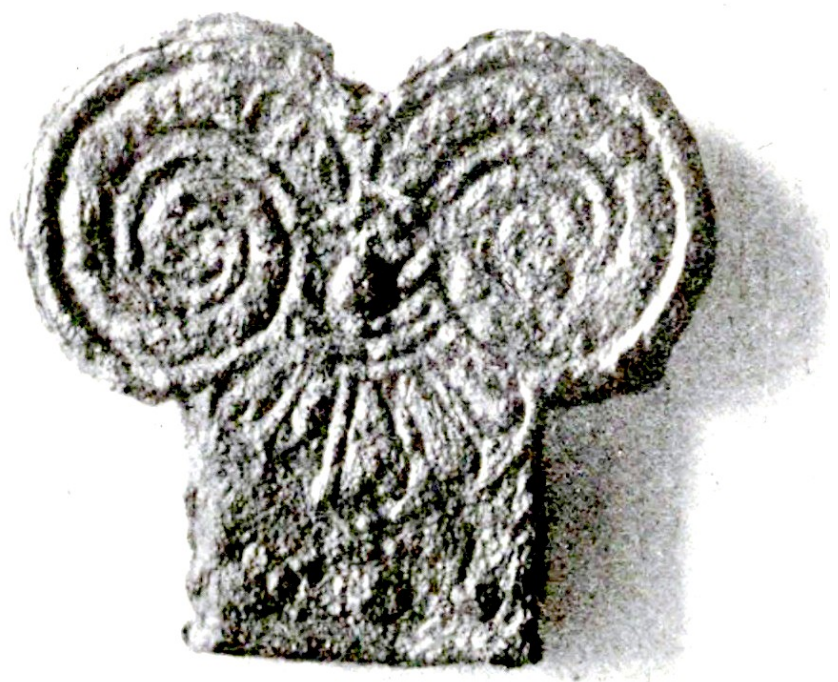

Рис. 4. Бронзовая накладка из ольвийского погребения «5/1905».

Изредка случалось так, что Б.В. Фармаковский публиковал в Archäologischer Anzeiger находки, обнаруженные в предыдущие годы, но это всегда оговаривалось. Например, в заметке посвященной раскопкам 1906 г., им была включена находка, сделанная в 1905 г. на ольвийском некрополе. В разграбленном погребении (5/1905), которое Б.В. Фармаковский отнес к VI в. до н.э., им было обнаружено две плоские бронзовые накладки по форме напоминающие капитель с двумя волютами, относящиеся к эпохе архаики. Борис Владимирович предположил, что данные накладки украшали изделие из железа (возможно кинжал или меч) и были скреплены 4 бронзовыми гвоздями (рис. 4). Позже, в Отчетах археологической комиссии за 1905 год

\footnotetext{
9 Pharmakowsky B. Südrussland // Archäologischer Anzeiger. 1906. № 2. S. 109-124. 10 Ibidem.
} 
(они были изданы в 1908 г.), Б.В. Фармаковский пересмотрел свою точку зрения, предположив, что данные накладки могли быть ручками медных зеркал. Тем не менее, публикация в Archäologischer Anzeiger также важна, поскольку отражает другую, раннюю точку зрения исследователя, а также содержит более качественную фотографию одной из накладок. Отметим, что в монографию Варвары Михайловны Скудновой, посвященной архаическому некрополю Ольвии данное погребение не включено, поскольку весь материал из раскопок ольвийского некрополя стал поступать в Эрмитаж (на основе коллекции которого создана монография В.М. Скудновой) начиная с 1909 г., а до этого находки также поступали в коллекции Одесского, Николаевского и Херсонского музеев, в также в Государственный исторический музей Москвы.

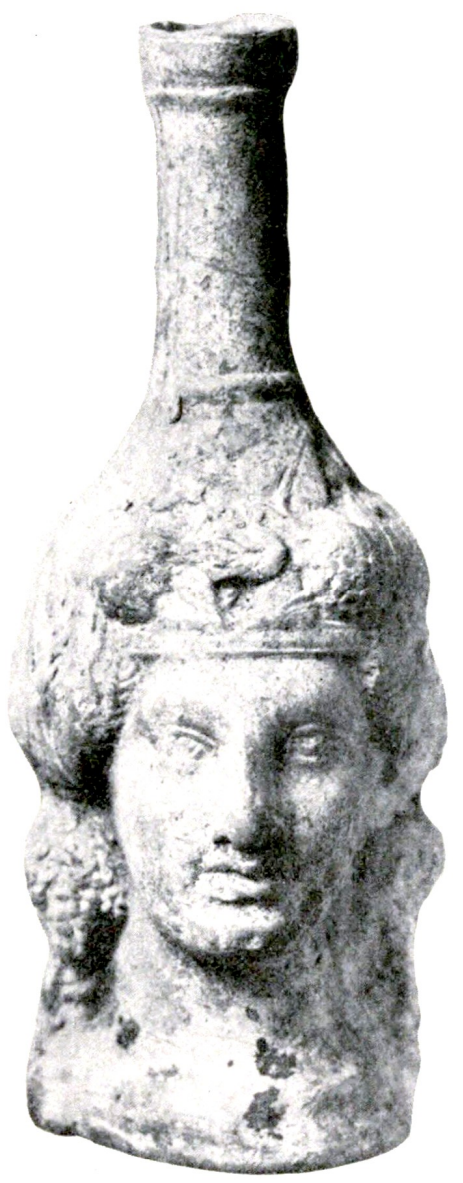

Рис. 5. Фигурный сосуд в форме головы Менады.

Иногда в Archäologischer Anzeiger была опубликована информация об ольвийских находках, фотографии которых не были представлены в отечественных изданиях. Так, в 1907 г. Императорской археологической комиссией были приобретены предметы из Ольвии, в том числе фигурный сосуд в форме головы Менады (рис. 5). Также в Archäologischer Anzeiger фотографии раскопанных объектов в некоторых случаях подавались в других ракурсах, нежели в Отчетах археологической комиссии. Например, такова фотография каменного склепа с двускатной крышей, раскопанного в 1908 г. (рис. 6).

Особенно много дополнительной информации об исследованиях Ольвии содержится в последних довоенных публикациях за 19111913 гг. Например, в заметке о раскопках ольвийского некрополя в 1911 г. есть фотография погребения № 78, где сожженный прах покойного был положен в чернолаковый сосуд, а вокруг него располагались 17 хиосских позднепухлогорлых амфор (рис. 7). До этого данное погребение было известно только по прорисовке в Отчетах археологической комиссии за соответствующий год.

Во время раскопок в 1912 г. был исследован курган в урочище «сто могил», относящийся к эллинистическому времени, в основном погребении которого были обнаружены золотые штампованные бляшки, а также золотая подвеска в виде женской головы со стефаной. Фотография данных находок была помещена автором только в Археологическом вестнике (рис. 8).

Tо, что в Archäologischer Anzeiger подчас содержатся уникальные сведения о раскопках Ольвии, было связано с тем, что если по результатам своих ранних археологических исследований за 1901 и 1902-1903 гг. Б.В. Фармаковским были созданы исчерпывающие отчеты-публикации на русском языке, то в дальнейшем такие из- 
дания прекратились вплоть до 1926 г. - самого последнего полевого сезона исследователя, опубликованного уже после его кончины. Описания же раскопок в Отчетах археологической комиссии не были настолько всеобъемлющими, особенно кратко подавалась информация о раскопках ольвийского некрополя.

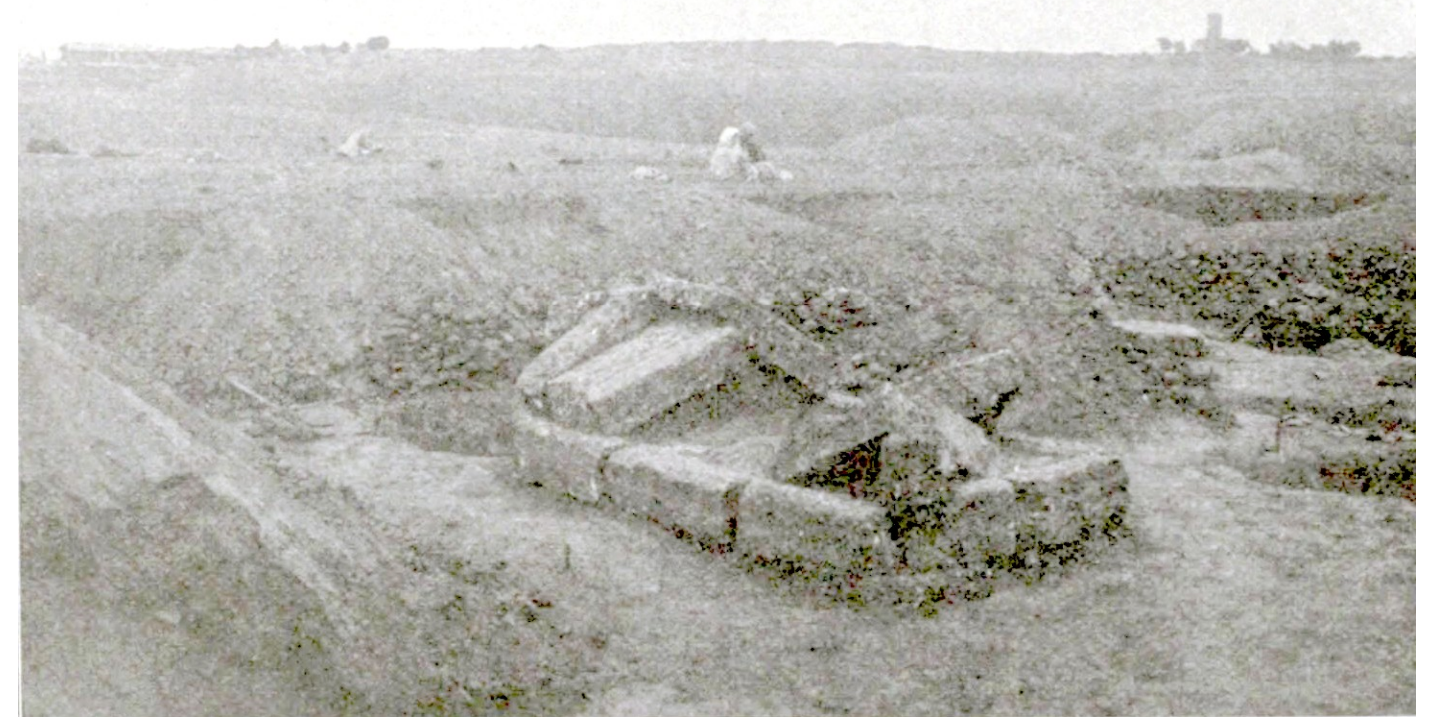

Рис. 6. Каменный склеп с двускатной крышей, раскопанный в 1908 г.

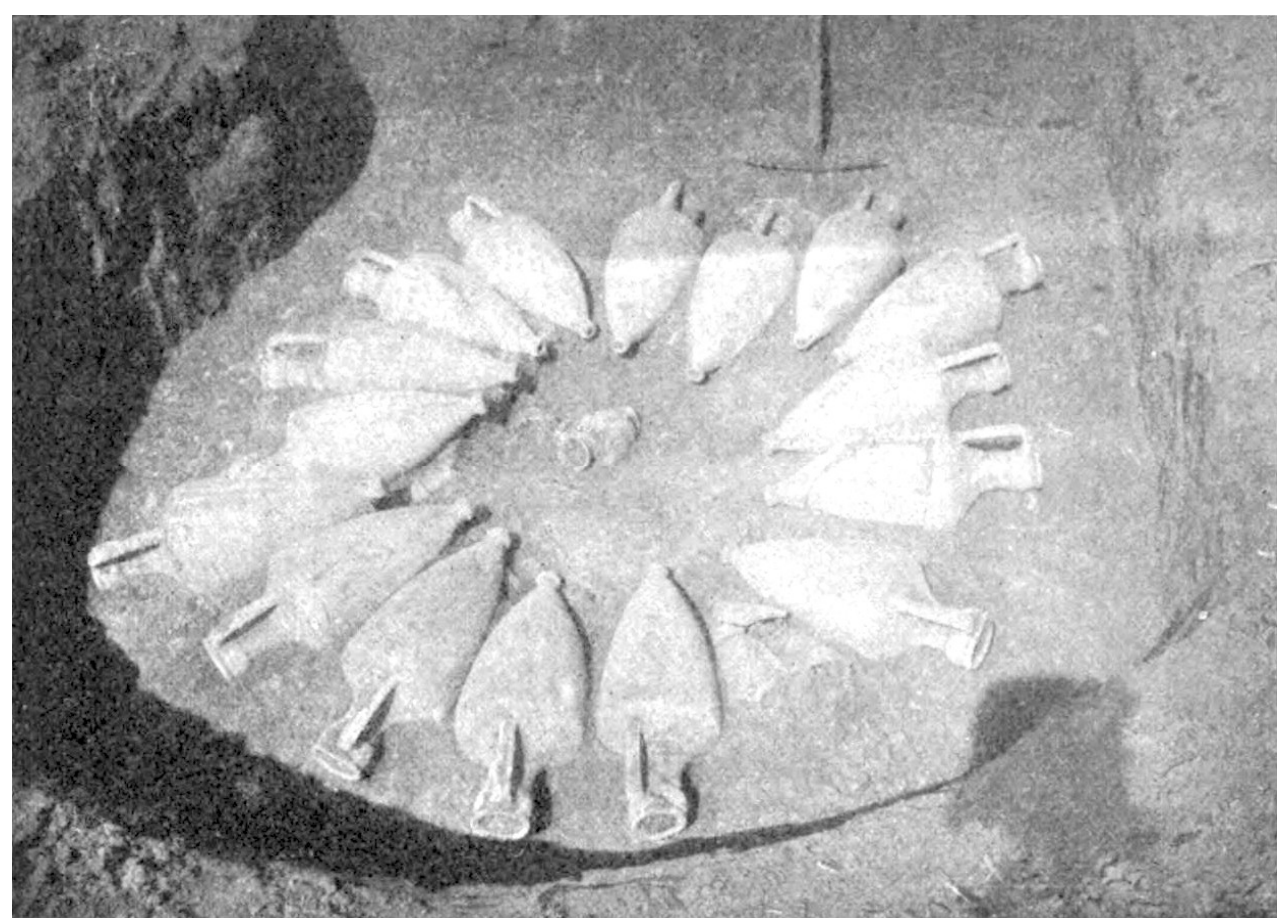

Рис. 7. Фотография ольвийского погребения «78/1911». 
Б.В. Фармаковский планировал издать серию отдельных подробных публикаций по раскопкам как ольвийского некрополя, так и городища, как он это делал ранее. Об этом упоминал сам автор, в частности на страницах ОАК за 1912 г.11 Но этим планам не суждено было сбыться в полной мере, была издана лишь часть находок архаической эпохи на страницах Материалов по археологии России ${ }^{12}$.
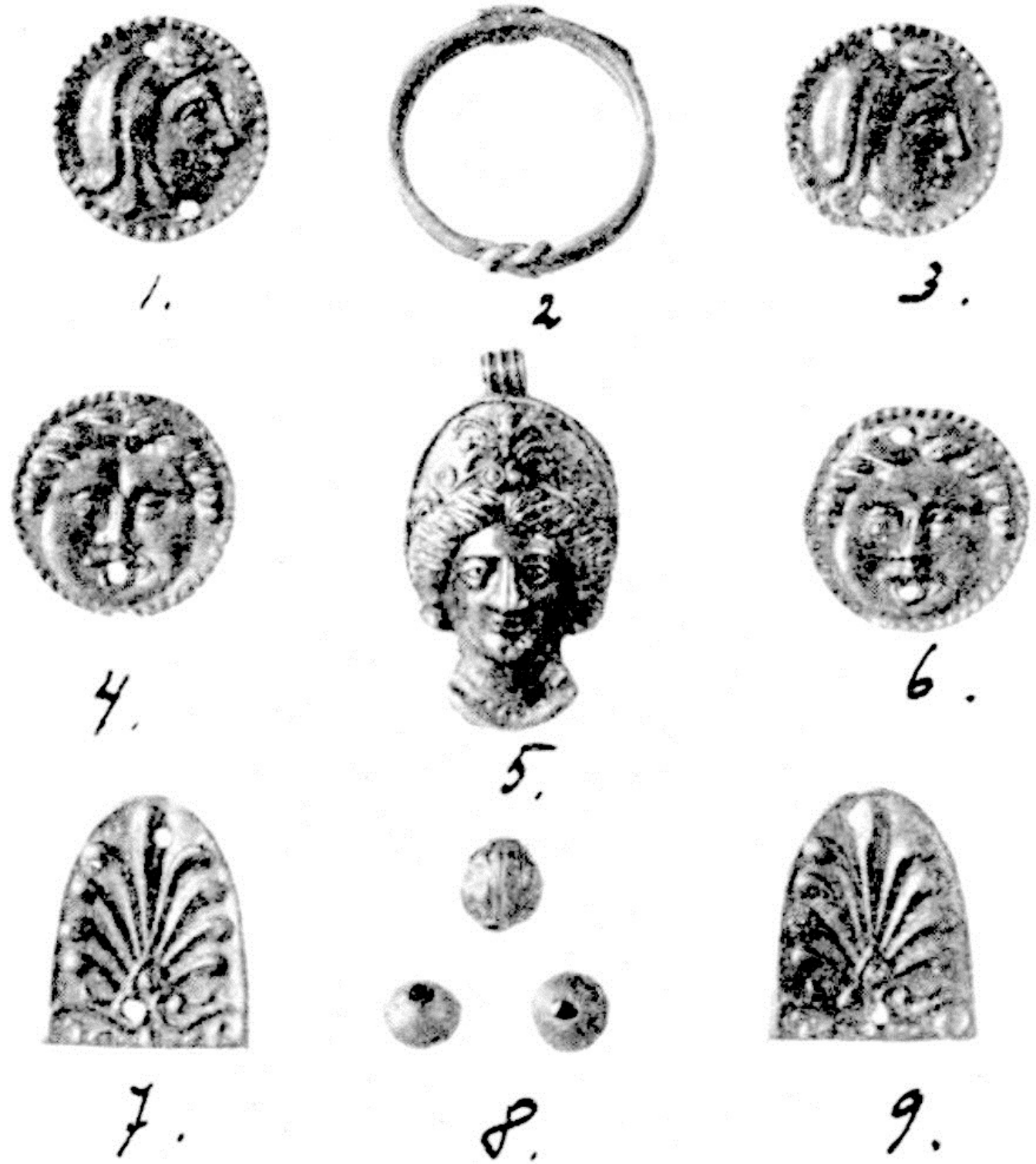

Рис. 8. Золотые вещи из кургана, раскопанного в 1912 г.

11 Фармаковский Б.В. Раскопки в Ольвии // Отчет Императорской археологической комиссии за 1912 год. 1916. С. 1-35.

12 Фармаковский Б.В. Архаический период в России // Материалы по археологии России. 1916. № 34. С. 15-78. 
Информация, посвященная находкам с ольвийского городища и некрополя, их фотографии, важны еще и потому, что у многих из них впоследствии были утрачены инвентарные номера, а, как отмечала В.М.Скуднова, «описания в дневниках настолько суммарны... что не могут помочь выяснению происхождению находок»13. Новые данные, почерпнутые из зарубежных публикаций, могут помочь в их идентификации.

Поэтому публикации результатов исследований в Археологическом вестнике представляют не только историографический, но и практический интерес, позволяя узнать новую информацию, либо уточнить имеющуюся, по раскопкам Ольвии начала XX века.

\section{REFERENCES}

Dragendorff, H. (1897). Archäologische Mitteilungen aus Süd-Russland. Archäologischer Anzeiger, 1, 1-8 [in German].

Farmakovskii, B.V. (1903). Raskopki nekropolia drevnei Olvii v 1901 godu [Excavations of the ancient Olbia necropolis in 1901]. Izvestiia arkheologicheskoi komissii, 8, 1-113 [in Russian].

Farmakovskii, B.V. (1904) Raskopki v Olvii [Excavations in Olbia]. Otchet imperatorskoi arkheologicheskoi komissii za 1902 god, 2-27 [in Russian].

Farmakovskii, B.V. (1906). Raskopki v Olvii v 1902-1903 godakh [Excavations in Olbia in the years 1902-1903]. Izvestiia arkheologicheskoi komissii, 13, 1-306 [in Russian].

Farmakovskii, B.V. (1908) Raskopki v Olvii [Excavations in Olbia]. Otchet imperatorskoi arkheologicheskoi komissii za 1905 god, 1-35 [in Russian].

Farmakovskii, B.V. (1912). Raskopki v Olvii [Excavations in Olbia]. Otchet imperatorskoi arkheologicheskoi komissii za 1908 god, 1-84. [in Russian].

Farmakovskii, B.V. (1914). Raskopki v Olvii [Excavations in Olbia]. Otchet imperatorskoi arkheologicheskoi komissii za 1911 god, 1-25 [in Russian].

Farmakovskii, B.V. (1916). Arkhaicheskii period v Rossii [Archaic period in Russia]. Materialy po arkheologii Rossii, 34, 15-78 [in Russian].

Farmakovskii, B.V. (1916). Raskopki v Olvii [Excavations in Olbia]. Otchet imperatorskoi arkheologicheskoi komissii za 1912 god, 1-35 [in Russian].

Farmakovskyi, B.V. (1929). Rozkopuvannya Ol'biyi r. 1926. Zvit [Excavation of Olbia, 1926. Report]. Odessa, 1929. [in Ukrainian].

Khmelevskyi, D.M. (2018). Pivnichna oboronna liniia rymskoi tsytadeli v Olvii [Northern defensive line of the Roman citadel in Olbia]. Arkheolohiia, 4, 95-105 [in Ukrainian].

Kieseritzky, G. (1899). Funde in Südrussland. Archäologischer Anzeiger, 2, 56-57 [in German].

Kieseritzky, G. (1901). Funde in Südrussland. Archäologischer Anzeiger, 2, 55-57 [in German].

Kieseritzky, G. (1902). Funde in Südrussland. Archäologischer Anzeiger, 2, 44-46 [in German].

Kieseritzky, G. (1903). Funde in Südrussland. Archäologischer Anzeiger, 1, 84-85 [in German].

Loeschcke, G. (1891). Erwerbungsberichte der deutschen Universitätssammlungen. Bonn. Archäologischer Anzeiger, 1, 14-20 [in German].

Parovich-Peshikan, M. (1974). Nekropol Olvii ellinisticheskogo vremeni [Necropolis of Olbia, Hellenistic time]. Kiev: «Naukova dumka» [in Russian].

Pharmakowsky, B. (1906). Südrussland. Archäologischer Anzeiger, 2, 109-124 [in German].

Pharmakowsky, B. (1907). Südrußland. Archäologischer Anzeiger, 2, 126-153 [in German].

Pharmakowsky, B. (1908). Südrußland. Archäologischer Anzeiger, 2, 149-192 [in German].

Pharmakowsky, B. (1909). Rußland. Archäologischer Anzeiger, 2, 139-176 [in German].

Pharmakowsky, B. (1912). Rußland. Archäologischer Anzeiger, 3, 323-381 [in German].

Pharmakowsky, B. (1913). Rußland. Archäologischer Anzeiger, 3, 178-234 [in German].

Pharmakowsky, von B. (1904). Funde in Südrussland im Jahre 1903. Archäologischer Anzeiger, 2, 100107 [in German].

Pharmakowsky, von B.W. (1905). Die Funde in Südrussland im Jahre 1904. Archäologischer Anzeiger, 2, 57-65 [in German].

Skudnova, V.M. (1988) Arkhaicheskii nekropol Olvii [Archaic necropolis of Olbia]. Leningrad: «Iskusstvo» [in Russian].

\footnotetext{
${ }_{13}$ Скуднова В.М. Архаический некрополь Ольвии: публикация одной коллекции. Ленинград: Искусство, 1988. С. 5.
} 
Stern, E. (1887). Compte rendu de la littérature russe de la philologie classique. 1884-1885. Revue de philologie, de litterature et d'histoire anciennes, 11, 337-342 [in French].

Stern, E. (1889). Compte rendu de la littérature russe de la philologie classique. 1886-1888. Revue de philologie, de litterature et d'histoire anciennes, 13, 371-385 [in French].

Stern, E. (1890). Compte rendu de la littérature russe de la philologie classique. 1889. Revue de philologie, de litterature et d'histoire anciennes, 14, 343-351 [in French].

Stern, E. (1891). Compte rendu de la littérature russe de la philologie classique. 1890. Revue de philologie, de littérature et d'histoire anciennes, 15, 357-368 [in French].

Zhebelev, S.A. (1923). Vvedenie v arkheologiiu. Chast I. Istoriia arkheologicheskogo znaniia [Introduction to archeology. Part I. History of archaeological knowledge]. Petrograd: «Nauka i shkola» [in Russian].

\section{Oleksandr Kuzmishchev}

(Institute of Archaeology of National Academy of Sciences of Ukraine, Kyiv, Ukraine) ORCID: https://orcid.org/0000-0003-2718-7111

\section{Excavations of Olbia in the Archäologischer Anzeiger (late $19^{\text {th }}-$ early $20^{\text {th }}$ century)}

Representatives of the archaeological community of the $19^{\text {th }}$ - early $20^{\text {th }}$ century including scholars, specializing in the study of antiquities of the Northern Black Sea region, closely cooperated with each other, exchanging information about the conducted researches on the pages of not only home but also foreign publications. At the same time, the historiography of publications devoted to archaeological studies of the Northern Black Sea region in European editions of the late $19^{\text {th }}$ - early $20^{\text {th }}$ century is practically absent. Thus, taking into account the increased interest in the history of archaeological science formation, as well as the study of the excavations results of the early $20^{\text {th }}$ century at a new scientific and methodological level, such research appears to be sufficiently reasonable.

The paper deals with notes on the pages of the German journal Archäologischer Anzeiger, devoted to the excavations of Olbia, from 1891 to 1913. Their content, information about the authors is described, also it is indicated that the part of the information, published there had no analogues in the home publications of the same period.

In 1891, G. Loeschcke published an article about the purchase of findings from Olbia by the University of Bonn. In 1897, a note, devoted to the archaeological assemblages of the Northern Black Sea region, written by H. Dragendorff, was published. In 1899 and 1901-1903 the information on archaeological findings was published by G. E. Kizeritskyi. But the most detailed information about the excavations of Olbia was published by their author, B.V. Farmakovskyi, who provided information about archaeological researches conducted by him in 1903-1913. Notes of B.V. Farmakovskyi comprise a textual description of what was studied in the past year and photographs, not all of which were included in Russian-language publications, for example, the Reports of the Archaeological Commission (RAC) and News of the Archaeological Commission (NAC).

New information on excavations and findings, their photographs, besides historiographic interest, are also important because some inventory numbers of the artifacts were subsequently lost. New information, gained from foreign publications, can help in their identification. Therefore, the publications of the excavations results in the Archaeological Bulletin are of not only historiographic but also of practical interest, allowing to find out new or to clarify the available information on the excavations of Olbia in early $20^{\text {th }}$ century.

Keywords: History of Archeology, Olbia, the Archäologischer Anzeiger, early $20^{\text {th }}$ century, B.V. Farmakovskyi 